УДК 7.071.2(73)

DOI:

Ольга Мартинів, викладач кафедри культурології та мистецької освіти Дрогобиџького державного педагогічного університету імені Івана Франка

\title{
ТВОРЧІСТЬ МАРТИ ГРЕМ В КОНТЕКСТІ СТАНОВЛЕННЯ ТАНЦЮ МОДЕРН
}

У статті досліджено вплив творчості Марти Грем (Грехем) на становлення та розвиток американської школи танцю. Розглянуто творчий шлях танцівниці та проаналізовано авторську техніку contraction and reliese, яку таниівниия формувала поступово впродовж багатьох років $і$ яка являсться основою танцю модерн і сьогодні. Виявлено трансформацію постановок М. Грем від демонстрації соціальних проблем шляхом звільнення тіла від академізму до сюжетних постановок з тонкою філософією і великим психологізмом.

Ключові слова: модернізм; Марта Грем; авторська техніка; танецьь модерн; балетна школа; хореографія; трансформація.

Jim. 11.

Olha Martyniv, Lecturer of the Culturology and Art Education Department Drohobych Ivan Franko State Pedagogical University

\section{CREATIVITY OF MARTHA GRAHAM IN THE CONTEXT OF MODERN DANCE}

Martha Graham is one of the founders of modern dance. During the XX century, she was the director of more than 180 ballets. She is famous for a significant contribution to modern dance and American culture. This article explores the influence of Martha Graham's creativity on the formation and development of the American dance school. The creative way of the dancer is considered and the author's technique contraction and reliese, which dancer has gradually formed for many years and which is the basis of modern dance today, is analyzed. Trying to understand the truth, the dancers of "dance modern" were interested in the issues of the future fate of the people, how it will affect the historical past, how it will affect its formation of traditions, life circumstances, etc. All this inspired Graham for new productions. Turning to the past, the dancer wanted to find an important truth for herself. In the 1940s, M. Graham's works received enormous and rebellious psychology. This is not just a concert work, but a whole emotional theatrical performance. M. Graham, in her productions, was able to glean subtlely and transfer to dance techniques exactly the emotional side that people at that time could not publicly demonstrate. It was very close to the background of the culture of postmodern American society, which emphasized subconscious motivations. Confidently moving toward modern dance, M. Graham creates her own "Martha Graham Dance Company", which was not like any other, thanks to an individual style and bold experiments. Seventy years a renowned dancer devotes herself to choreographic art. She was the first who traveled through her art beyond the sea, who had the honor at the time to appear in the White House and the first to receive the highest civilian award - the Presidential Medal of Freedom. Thanks to Graham, the dance became a plot that was not typical of classical choreography, ballets and productions, was saturated with subtle philosophy and psychology, which created emotional tension, and the bodies of dancers were most liberated in the reproduction of natural emotions. As a result, her technology is reduced and the release is mastered by many followers and occupies a significant place in the context of modern choreography.

Keywords: modernism; Martha Graham; the author's technique; modern dance; a ballet school; choreography; transformation.

П остановка проблеми. Марта Грем являється однією із засновниць сучасного танцю. Протягом ХХ ст. була постановником більш як 180 балетів. Ї̈̈ пам'ятають за вагомий внесок в сучасний танець і американську культуру. Крізь призму їі балетів можна побачити історію Америки і проблеми того часу. Для того, щоб зрозуміти, як Марта Грем вплинула на танець того часу, важливо знати, що саме сприяло розвитку "вільного танцю".

Аналіз останніх досліджень і публікацій. Проблему виникнення та формування нових танцювальних напрямків висвітлено у ряді публікацій В. Нікітіна, Н. Аркіної, К. Добротворської, I. Мордовіної, Д. Бернадської, О. Чепалова,
М. Погребняк, Д. Шарикова та ін. А також зарубіжні дослідники такі як Р. Трейсі, Р. Фрідман, Б. Иорган теж торкаються даної проблематики, але в контексті творчості танцівниці Марти Грем.

Мета статті - дослідити вплив творчості Марти Грем на формування танцю модерн, або "вільного танцю".

Виклад основного дослідження. Сучасний танець являється свого роду формою танцю, яка склалася в кін. 1800 -х і поч. $1900-x$ років в Америці і Європі. Приблизно в цей же час, світ втомився від балету. Люди вважали, що балет став занадто строгим і жорстким і відтак почали шукати нові форми танцю, що допоможугь виразити себе $[8,13]$.

Айседора Дункан і Руф Сен-Дені вважаються 
засновницями сучасного танцю, який зародився в кінці 1870 -х років. Ці американки розчистили шлях для сучасного танцю, досліджували “танець” і згодом створили більш природний стиль, в якому беруть участь босі ноги і плавні рухи тіла. Ці дві жінки зробили важливими зміни в світі танцю, вивчення танцювальних стилів зі всього світу і розширення ідей і тем, які можуть бути виражені через танцювальний рух $[6,34]$. Взагалі, 1800 роки характерні тим, що змін потребували усі, не тільки в світі танцю, який в цей час відкидає класичну, традиційну форму танцю, як балет. Це прагнення до новизни було частиною руху під назвою модернізм.

Модернізм почався в середині 19 ст. у Франції і поступово розповсюджувався по всіх куточках світу. Художники, такі як Ван Гог і Пікассо більше не були зацікавлені в живописі людей, яких писали протягом віків і не хотіли виражати точну копію того, що вони бачили. Вони прагнули захопити сцени повсякденного життя, експерементуючи 3 мазками і світлом [3, 8]. Музиканти, письменники, скульптори і мислителі всі вони експериментували 3 новими методами і новими способами дивитися на світ. Але ж чим було викликано це бажання новизни? Багато факторів призвели до модернізму, але один із самих вагомих - війни. В кінці 1700-х і поч. 1800-х років, було багато війн і революцій по всьому світу. Люди почали думати про права людини i свободу i через крах всього навколишнього потреба новизни загострилася $\mathrm{i}$ стала необхідною. Художні форми, такі як сучасний танець теж намагались осмислити знищення в світі. Він являється результатом великих змін, які виникли в світі за останні 200 років. Якраз в роботах Марти Грем прослідковується історія Америки [4, 332].

Марта Грем народилась в сучасному Пітзбурзі, штат Пенсельванія. Їі сім'я переїхала в СантаБарбару, коли дівчинці було 14 років. І в Каліфорнії вона почала свою танцювальну кар'єру. Батько Грем дуже вплинув на ії життя. Він був лікарем пацієнтів 3 психічними розладами і був зацікавлений у здібностях людського організму виражати емоції. Цей досвід чітко прослідковується в творчості танцівниці. Протягом семи років свого навчання в школі танцю “Денішоун” в Лос-Анджелесі, Марта Грем пізнавала історію грецької філософії, цікавилася костюмами, народними танцями, макіяжем та музикою. Всі ці набугі знання і навики вона згодом застосує у своїй власній танцювальній школі. На початку своєї кар'єри Грем працювала без заробітньої плати, її виступи не були частими і вона вимушена була шити костюми власноруч, що ще більше похитувало їі матеріальне становище. Але з часом повага до творчості Марти Грем збільшувалася і їі мистецтво оцінювало все більше людей і чиновників. Свій стиль і метод навчання вона допрацьовувала на протязі всієї багатої кар'єри. Всі 180 робіт Грем відображають швидкоплинний світ. Тим не менше, скільки б не мінявся стиль Грем, він завжди обертався навколо концепції скорочення і розширення (contraction i release) $[1,120]$.

Ці два терміни пов’язані з положенням корпусу, рук і ніг. Contraction - скорочення, тобто відносне зменшення об'єму тіла. Протилежне поняття realese, тобто розширення, коли тіло розширюється в просторі. Contraction i realese це базові поняття , що закладені в техніці Грем, а згодом запозичені й іншими системами. Сама Марта Грем стверджувала, що contraction починається в середині тазу, а потім розповсюджується у напрямку вверх, охоплюючи весь поперек і останньою в рух приводиться голова. Аналогічно, знизу вверх, виконується realese. Якщо в балеті все заокруглено положення рук, м'які переходи з пози в позу, то в танці Грем на перше місце висунуті кутові різкі рухи. В даній техніці все різко, чітко, поривчасто, напружено. Погляд не відпочиває, а безперервно контактує 3 навколишнім світом, який теж наповнений нерівностями і гострими кугами $[7,80]$.

Техніка М. Грем формувалася поступово протягом багатьох років. Грем завжди засуджувала делетантизм і вважала, що танцюрист повинен розвивати своє тіло, щоб зробити його слухняним інструментом для, власне, самого танцю. Займатися самовдосконаленням, на її думку, потрібно завжди і всюди та безперервно вивчати можливості свого тіла. А для повної влади над ним потрібен постійний жорсткий тренаж. Спочатку, заперечуючи, як і всі танцюристи цього напрямку, балетну хореографію, М. Грем демонстративно відкидала і класичний тренаж. Згодом, як вона зізнавалась сама, артистка зрозуміла, що безглуздо ігнорувати те, що досягло трьохсотлітнього досвіду, і все таки запозичила з класичного танцю те, що здавалося іій корисним $[9,66]$.

Намагаючись зрозуміти себе, танцівники “танцю модерн” цікавилися питаннями подальшої долі народу, як відобразиться на ньому історичне минуле, як вплинуть на його формування традиції, життєві обставини і т.д. Це все надихнуло Грем на такі постановки як: “Древні містеріі” (1931), “Границя” (1935), “Американський документ” (1938), “Весна в Аппалачах” (1944). Звертаючись до минулого, хореограф намагалася виокремити 


\section{ТВОРЧІСТЬМАРТИГРЕМ В КОНТЕКСТІ СТАНОВЛЕННЯТАНЦЮ МОДЕРН}

в ньому першочергове i важливе для майбутнього. Ці танці розказували про силу і терпіння піонерів, що завоювали нові землі.

Коли Грем ставила "Весну в Аппалачах", в танці переважали широкі, впевнені, вільні та відкриті рухи. Танцівниця все більше занурювалася у соціальні проблеми, намагаючись знайти шляхи вирішення, звертається до творчості письменниць і поетес, яких прискіпливо вивчала. Таким чином соціальні проблеми переростали у проблеми психологічні $[11,135]$. Протягом 1940-х років постановки М. Грем набули масштабності і бунтуючого психологізму. Це вже не були прості концертні номери, а цілий театр в основі якого завжди лежала напружена емоція. Відтак, в мистецтві Марти Грем виник новий тип танцювальної драми, де розповідалося не стільки про зовнішні події, скільки про душевні переживання $з$ усіма можливими барвами. Вона часто зверталася в своїх постановках до образів античних і біблійних, церковних міфів. Так виникли балети про Іродіаду - “Печера серця” 1946, Едипі і Іокасті - “Подорож вночі" 1947, Аріадні і Тезея - “Із звісткою в лабіринт” 1947, Жанну д’Арк “Діалог серафимів” 1955 та ін. У цих постановках Марта Грем піддала глибокому аналізу душі своїх героїв та героїнь, відчуваючи тонкі емоційні нюанси, проникаючи в підсвідоме. При цьому це були абсолютно сучасні постановки [2, 167]. Відтак бачимо, що танець ставав засобом самоаналізу, що співпало з тенденціями сучасного мистецтва і літератури, які особливу увагу приділяли психологічному аналізу індивіда, розкриваючи емоційний досвід, виявляючи приховані мотиви вчинків. Такий танець також забезпечував потреби сучасного американця, який вирішував свої психологічні проблеми за допомогою психоаналізу, який в ті роки здобув широку популярність.

М. Грем у своїх постановках уміла тонко вловити і передати у танцювальних прийомах саме ту емоційну грань, яку люди того часу не могли публічно демонструвати. Це було дуже влучно на фоні культури постмодерністського американського суспільства, яке акцентувало увагу на підсвідомих мотиваціях [5, 62]. Відтак, вона намагалася донести до людей не саму танцювальну техніку, а, власне, істину, що криється в ній. Але занурення Грем у такий глибокий психоаналіз у постановках зовсім не заперечувало виснажливі щоденні тренування, якими вона переймалася не менше.

Згодом, танець Марти Грем переростав у стадію вже тонкої філософії, яка розкріпачувала людину у всіх іiї проявах. В період iї творчості у світі існував сталий стереотип про те, що чоловіки танцюють прямолінійними рухами і церебральними, натомість - жінки у танці виражають себе у плавних рухах і є більш емоційними. Суть хореографії і філософії Грем передбачала стерти всі умовності, зробити своїх персонажів безособовими і сильними як духовно, так і фізично. На думку Грем, в тілі танцюриста повинна відображатися, насамперед, людина, а не чоловік, чи жінка.

Марта Грем творила креативно, залучаючи до свого мистецтва практично всі жанри. Працюючи iз музикантами, художниками, композиторами, дизайнерами, скульпторами, танцівниця створила постановки-вистави 3 неймовірно емоційним наповненням. Цим “вільним танцем” їй вдалося звільнити і жінку, і танець. Впевнено рухаючись у напрямку модерного танцю, М. Грем створює власну трупу "Martha Graham Dance Company", що не була схожа з будь-якою іншою, завдяки індивідуальному стилю і сміливим експериментам.

Мистецтво Сходу, фольклор афроамериканців та сюжети античної і біблійної міфології відіграють важливу роль у подальшій творчості і призводять до перетину традицій і канонів. Школа Марти Грем реалізувала техніку і особливості танцю модерн найбільш повно серед усіх митців того періоду, тому їі вважають найбільш характерною серед співзасновників. "Martha Graham Dance Company” опісля гастрольного туру Свропою i Близьким Сходом, де були продемонстровані новації Грем, по праву отримує міжнародне визнання і американський модерний танець остаточно закріплюється у Свропі.

Такий невпинний рух вперед, безперервні тренування у пошуках істини, постійна емоційна напруга сприяли різкому погіршенню здоров'я, відходу зі сцени i, як наслідок, розвитку глибокої депресії, що живилася молодими, енергійними та повними фізичних сил танцюристами. Грем почала зловживати алкоголем, щоб якось приглушити цей стан безпорадності і очевидного старіння. Вона ніяк не могла прийняти той факт, що хтось танцює краще за неї, що на когось із захватом дивляться так, як колись захоплювалися нею. Вона просто перестала танцювати, зачинившись вдома, вона пила, дуже мало їла i роздумувала над буттям. Остаточно втративши волю до життя після невдалого самогубства Марта Грем була госпіталізована. Це було для неї першим кроком до психологічного та фізичного відновлення. Опанувавши себе, Грем повертається в танцювальну студію, де реорганізовує свою трупу і починає плідну роботу над десятками нових балетів та постановок. 


\section{ТВОРЧІСТЬМАРТИ ГРЕМ В КОНТЕКСТІ СТАНОВЛЕННЯ ТАНЦЮ МОДЕРН}

Висновки. Марта Грем (Грехем) увійшла в історію танцю, як жінка феміністка, хоча сама Марта до феміністського руху себе зовсім не відносила, як людина, яка створила і очолила революційний рух у світі хореографії і створила те, що сьогодні зветься сучасним танцем в цілому світі. Його вивчають і досі намагаються осмислити філософський зміст, а професійні хореографи надихаються ним на нові творчі звершення. Більше сімдесяти років відома танцівниця присвятила хореографічному мистецтву. Вона була першою, хто подорожував зі своїм мистецтвом за моря, хто мав честь, в ті часи, виступати в Білому домі і першою, хто отримав найвищу цивільну нагороду Президентську Медаль Свободи.

Їй вдалося шляхом новаторства звільнити танець від академізму, що зробило його більш зрозумілим і близьким глядачу. Танець, завдяки Грем, почав будуватися на основі сюжетів, які були не властиві класичній хореографії. Балети і постановки були насичені тонкою філософією та психологізмом, який і створював емоційну напругу, а тіла танцюристів отримали найбільше визволення у відтворенні природних емоцій. Як результат, іiі техніка contraction і reliese, освоєна багатьма послідовниками і займає вагоме місце в контексті сучасної хореографії.

\section{ЛIТЕРАТУРА}

1. Graham M. Blood Memory: Anautobiography / Martha Graham. - New York: Doubleday, 1991.-279 p.

2. Амчиславська Н. Жіночі образи в балетах М. Грем / Амчиславська Н. // Матер. конф. “Динаміка розвитку вищої хореографічної освіти як складової художньої культури України" (м. Київ, 17-18 квітня 2015 року). К., 2015. - С. 166-169.

3. Берданська Дарія Петрівна. Феномен синтезу мистецтв в сучасній українській сценічній хореографії: дис... канд. мистецтвознавства: 17.00.01 / Київський національний ун-т культури і мистецтв. -К., 2005.

4. Бутрова Т. От Системы к Методу // Западное искусство XX век. Проблема развития западного искусства ХХ века. - СПБ., 2001.-С. 328-349.

5. Колногузенко Б. М. Види мистецтва та хореографії / Б. М. Колногузенко. - Х. : ХДАК, 2009. - 140 с.

6. Колногузенко Б. М. Мистецтво балетмейстера / Б. М. Колногузенко. -Х.:ХДАК, 2007. - 85 с.

7.НикитинВ. Ю. Модерн-джаз танец:История. Методика. Практика.-М.: Изд-во “ГИТИС”, 2000-440с., іл.

8. Полятков С. С. Основы современного танца / С. С. Полятков. - Ростов-н-Д: Фенікс, 2005. - 80 с.

9. Шариков Д. І. Теорія, історія та практика сучасної хореографії. [Генезис і класифікація сучасної хореографії - напрями, стилі, види.]: Монографія / Шариков Д. І. - К.: КиМУ, 2010. - 208 с.

10. Шариков Д. І. Мистецтвознавча наука хореологія як феномен художньої культури. Типологія хореографії.: монографія / Шариков Д.І. - К. : КиМУ, 2013. - Частина III. -90 с. : іл.

11. Яніна-Ледовська Є. В. "Весна священна" I. Стравінського: принципи кваліфікації хореографічних трактувань / Яніна-Ледовська С. В. // Тенденції розвитку хореографічних дисциплін у вищих мистецьких навчальних закладах / Матеріали Всеукраїнської науково-практичної конференції. Київ, 11-12 квітня 2014 року. -К., 2014.-С. 133-138.

\section{REFERENCES}

1. Graham, M. (1991). Blood Memory.Anautobiography. New York: Doubleday, 279 p. [in English].

2. Amchyslavska, N. (2015). Zhinochi obrazy v baletakh M. Hrem [Women's images in ballet by M. Graham]. Kyiv, pp. 166-169. [in Ukrainian].

3. Berdanska Dariia Petrivna (2005). Fenomen syntezu mystetstv v suchasnii ukrainskii stsenichnii khoreohrafii [The phenomenon of synthesis of arts in contemporary Ukrainian stage choreography]. Candidate's thesis. Kyiv National University of Culture and Arts. Kyiv. [in Ukrainian].

4. Butrova, T. (2001). Ot Sistemy k Metodu [From System to Method] Western art of the twentieth century. The problem of the development of Western art of the twentieth century. St.Petersburg, pp. 328-349. [in Russian]

5. Kolnohuzenko, B. M. (2009). Vydy mystetstva ta khoreohrafii [Types of art and choreography]. Kharkiv: KhDAK, 140 p. [in Ukrainian].

6. Kolnohuzenko, B. M. (2007). Mystetstvo baletmeistera [The art of the choreographer]. Kharkiv: KhDAK, 85 p. [in Ukrainian].

7. Nikitin, V. Yu. (2000). Modern-dzhaz tanets: Istoriya. Metodika. Praktika [Modern jazz dance: History. Method. Practice]. Moscow: "GITIS", 440 p. [in Russian].

8. Polyatkov, S. S. (2005). Osnovy sovremennogo tantsa [Basics of modern dance]. Rostov to Don: Feniks, 80 p. [in Russian].

9. Sharykov, D. I. (2010). Teoriia, istoriia ta praktyka suchasnoi khoreohrafii [Theory, history and practice of modern choreography]. Kyiv: KiMU, 208 p. [in Ukrainian].

10. Sharykov, D. I. (2013). Mystetstvoznavcha nauka khoreolohiia yak fenomen khudozhnoi kultury. Typolohiia khoreohrafii [Art science science choreology as a phenomenon of artistic culture. Typology of choreography]. Kyiv: KiMU, vol 3, 90 p. [in Ukrainian].

11. Ianina-Ledovska, Ye. V. (2014). "Vesna sviashchenna" I. Stravinskoho: pryntsypy kvalifikatsii khoreohrafichnykh traktuvan [I. Stravinsky's "Holy Spring": the principles of the qualification of choreographic interpretations]. Tendentsii rozvytku khoreohrafichnykh dystsyplin u vyshchykh mystetskykh navchalnykh zakladakh. Materialy Vseukrainskoi naukovo-praktychnoi konferentsii - Trends in the Development of Choreographic Disciplines in Higher Artistic Educational Institutions. Proceedings of the AllUkrainian Scientific and Practical Conference. (pp.133138). Kyiv. [in Ukrainian].

Стаття надійшла до редакції 31.07.2018 